\title{
Land Use Land Cover Classification in Jamuna- Kotma Coal Field Region, Anuppur District MP
}

\author{
* Dr.Manisha Garg, **Dr.Arun Joshie*** Dr.Sandhya Choudhary \\ *** Associate Professor, Extension Education, College of Agriculture, Indore (MP) \\ ** Head, National Livelihood Resources Institute, GVT, Ratlam (MP) \\ * Research Officer, GIS Cell, National Livelihood Resources Institute, GVT, Ratlam (MP)
}

\begin{abstract}
The rate and intensity of land use/land cover (LU/LC) change has increased considerably during the past couple of decades. Mining brings significant alterations in LU/LC specifically due to its impact on forests. Parts of Central India are well endowed with both forests and minerals. Here, the conflict between human interests and nature has intensified over time. Monitoring and assessment of such conflicts are important for land management and policy making. Remote sensing and Geographical Information System have the potential to serve as accurate tools for environmental monitoring. The changing rules of the landscape elements and their distribution in Jamuna Kotma coal mining area are analyzed by means of topomap (1973) and remote sensing images obtained in, 2000, 2009. Using support vector machine classification method, it can be classified into six land-use types: water, agriculture, Forest, mining, settlement and waste land. In 1973 forest area was 174 sq. $\mathrm{km}$. while in 2000 it reduced $96 \mathrm{sq} . \mathrm{km}$. and in 2009 forest area were left only $68 \mathrm{sq} . \mathrm{km}$. Water bodies have increase due to the mining activities. In 2000 mining area was $47 \mathrm{sq} \mathrm{km}$. and in 2009 mining area had increased up to $64 \mathrm{sq} \mathrm{km}$. Agriculture land had been reduced from $167 \mathrm{sq}$. $\mathrm{km}$. (1973) to $110 \mathrm{sq}$. km. (2000) to $88 \mathrm{sq}$. $\mathrm{km}$ (2009). Waste lands have been continuously increasing since 1973 (26 sq km) to 2000 (81 sq km) to 2009 (93 sq $\mathrm{km})$.
\end{abstract}

Keywords: Land use, Land cover, Change Detection

\section{Introduction:}

Mining is a site-specific activity and is done at the sites where minerals exist. Also, mining is considered as an environmentally hostile activity. Global attention has been drawn towards the environmental impacts of mining and associated activities in mining complexes, and the action that are required to be taken for minimization prevention and mitigation of these impacts. The activities in mining complexes affect all the components of the environment and these effects could be temporary or permanent reversible or irreversible repairable or irreparable and beneficial or harmful. The growth of Indian coal industry has achieved very high rate since independence, especially after nationalization and this is accompanied by production of large volumes of hazardous solid, liquid and gaseous material during various mining and related activities. Due to the Mining activities topography and land use and land cover of the area are exceedingly changed. Forest area declined while the residential area increased. Besides this, waste land and water body has also been changed. It also affected the agricultural area. Land is the most important natural resource which embodies soil, water and associated flora and fauna involving the total ecosystem (Singh and Khanduri 2011; Chitade and Katyar 2010;Javed,2009) .Jamuna Kotma mining area is situated in Anuppur District of M.P. Area falls under SOI toposheet no. $64 \mathrm{E} / 16$ and $64 \mathrm{I} / 4$ in range of latitude in between $23^{\circ} 0^{\prime}$ and $23^{\circ} 15^{\prime}$ and longitude in between $81^{\circ} 45^{\prime}$ and $82^{\circ} 05^{\prime}$ (fig.1). Anuppur - Chirimiri section of SECL Railway is passing through it. National highway (78) passes along northern side of the area and River Kewai passes along north - south of the study area. The area is gently undulating with the general slope towards River Kewai. The surface attains maximum and minimum elevation of 573.47 and $512.42 \mathrm{~m}$ respectively from Mean Sea Level (MSL). The temperature varies from $4.9^{\circ} \mathrm{c}$ to $44^{\circ} \mathrm{c}$. Average annual rainfall is $1430 \mathrm{~mm}$. 


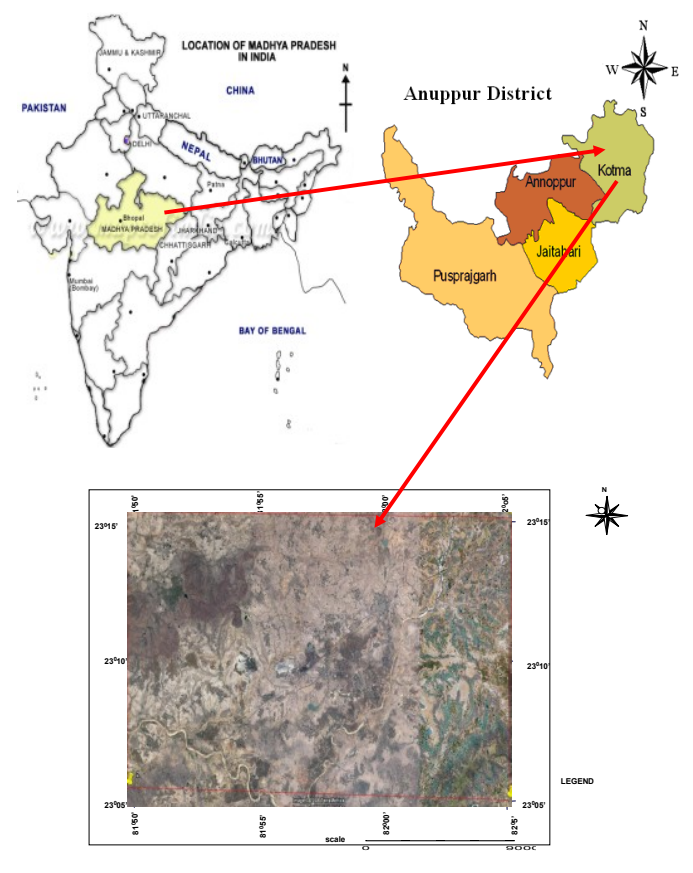

Fig. 1. Location Map of the area

\section{Data Preparation}

\section{Methodology}

The study was based on both topomap data and satellite data sources. The later Multi - temporal data were required to study the land use changes over a period of time. LANDSAT TM satellite data of 144 paths and 42 row of the area of intersect was downloaded from the USGS website. With the help of ERDAS 8.6 Image processing software the downloaded image was import in img. format. These data are stacked in a single file and mosaic with the help of ERDAS software. By overlaying the area of interest on mosaic image the imagery of Kotma, the area was subset with the help of subset tool. Since image orthorectified, the subset image ready for classification. Digital Image classification uses the spectral information represented by the digital numbers in one or more spectral bands and attempts to classify each individual pixel based on this spectral information (Kuang et. al., 2007; Peter et.al., 2005)

The process of image enhancement was applied for clarity and lineament identification. The polynomial of georeferenced rectified image was first classified with the help of classifier menu of ERDAS selecting unsupervised classification option. 10 numbers of classes was choosen for signature classes. Supervised classifications were also performed on the area of interest. Each selection was categorized according to landuse/landcoer index and added to signature editor and new color has been assigned. The classification of geomorphologic structure was done by visual interpretation of orthorectified LANDSAT imagery with the help of creating segment of morphological features and then polygon sing them.

Software used There were number of Remote sensing and GIS software packages. In the present study following software has been used: AutoCAD, Map-Info7.5, ILWIS 3.3, and ERDAS8.6

Material used: For various type of analysis, many types of data, materials and software were utilized in the present study. Data - The data used in present studies are as follows-

a. Satellite data- Land Sat TM and ETM data of 2000

b. Google Earth Data: Large scale map and terrain data of 2009

c. Topo map - SOI topo map 64E/ 16 and 64 I/4

For land use/ land cover analysis satellite data and SOI topo map has been utilized. LANDSAT ETM ortho rectified Satellite imagery data of the area having Path 144, Row 44 and Path 144, Row 43; dated October 2000 
has been downloaded from the Internet and was used for supervised classification of digital image processing to find out land use and land cover classes of the area. The survey of India (SOI) topo map no. 64 E/116 and $64 \mathrm{I} / 4$ was used for creating base line data themes, drainage pattern, water bodies and digital elevation model. Prepared base were modify by the satellite data. The base line data also helps in calculating drainage losses during mining activities in 1:50,000 Scale. The base map themes of the area were made with the help of Digital Elevation Model (DEM) was created with contour and point heights interpolation of the area as given in SOI topo map. The imagery of the mining area was superimposed DEM to create DTM. DEM helps in assessing slope and slope aspects which were important parameters in deciding flow direction of the area. The spectral bands (remotely sensed data) collected by the sensors, were stacked and mosaic. The area of interest was subset with the help of image processing software. The combination of infrared (band 4), red (band 3), and green (band 2) is used to prepare false color composite (FCC) of the area used. The remote sensing data were processed to investigate land use pattern through digital image processing techniques. Suitable image enhancements were then applied on the extracted area of interest. A visual interpretation followed by supervised classification (digital image processing approach) was adopted to classify various land use land cover features. Flow chart of Land use/Land cover mapping given in (fig. 2). Prior to supervised classification several training sets/signatures were collected for applying them for classification. After evaluating the statistical parameters of training sets, the training areas were rectified by deleting non-congruous training sets and creating new ones. The verification of the land use land cover was also carried out in the area with GPS tools.

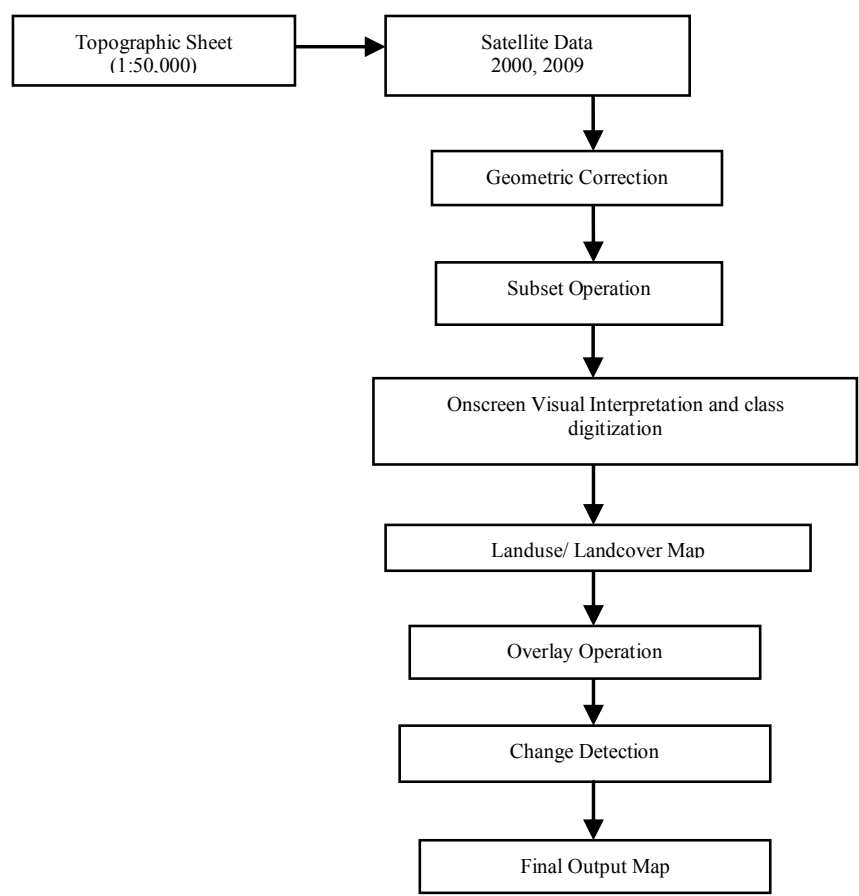

Fig.2 Flow chart of Methodology

\section{Land use/Land cover}

Digital elevation model of the area with superimposed proposed mine area showing general slope of the area towards south east (fig.3). The northeast area having higher elevation has a slope towards the Hasdeo river valley. The southeast area showing a depressed valley which drain outs the water from the area. FCC of the area shows that dense forest occupies north eastern part of the area while rest of the area is having localized forest cover (Fig.4, $5 \&$ 6). Maximum part of the area is under arable land use.

\section{Land use/ Land cover classification}

Land cover refers to the material/ object present in the particular terrain e.g. vegetation, water bodies, rocks/soils and other resulting form from land transformations. Although land use is generally inferred based on the cover, yet both the terms land use and land cover being closely related are interchangeable (Chaudhary et. al., 2008; Bhaumik and Tiwari 2008).Land refers to man's activities on land utilitarian in nature, where as land cover denotes to vegetation and artificial constructions. Visual interpretation technique was used for the detection, identification, delineation and characterization of land use and land cover types occurring in the 
physiological study area. The remote sensing images had been analyzed utilizing a variety of observable elements of a spectrum like size, shape, shadow, tone or color, texture, repetition of pattern, site, association and resolution (Estes and Simonett 1975).For the interpretation of the data, the false color composite paper prints were checked with the help of light table. A classification scheme had been finalized after careful scrutiny of the satellite data and the ancillary information gathered during the course of field surveys. Efforts were made to visit the study area several area times to verify the classification of land use/land cover features delineated and depicted in the satellite imageries. After careful scrutiny, final map is prepared (Tomos 2007; Tripathi et. al., 2007). The base map was prepared using survey of India (SOI) topographical sheets in 1:50,000 scale. Important land features like roads, rivers, railway lines etc were marked on the base maps. The details of the satellite imageries were transferred on the tracing films using simple light table. The final maps contained borders, legends and titles. Since the verification of the land use/land cover features physically on the ground, as depicted on satellite imageries of earlier dates can not be done .a new approach had been suggested by Indian space Research organization (ISRO) to overcome this difficulty. As per this, the current satellite data (2000) and (2009) was used as a template to analyze the old topographical sheet (1973). Copies of land use/land cover maps were superimposed. The rate of change in the various land use land cover categories had been varying very fast. The major causality was forest, followed by agricultural/cultivable land. The area under barren and blank category increased all through these years. Data obtained from satellite remote sensing images had been successfully used by number of worker in the assessment and monitoring of changes in land use/land cover classes. (Dobson et.al., 1992; Sinha et.al., 1982; Saxena and Pandey 1992; Majumdar and Sarkar 1994; Saraf et.al., 1995; Prakash, et.al., 1997) The decline in the forest area can be attributed mainly due to mining activities Mining related changes in the land use/ land cover have also been recorded by Garg and Sahai (1989), Kushwaha, and Oesten, (1995), Kushwaha et. al., (2000). A part from mining and industrial development, a large part of forests alarmingly damaged by other anthropogenic activities: Legal and illegal firewood and timber collection overgrazing by cattle, extension of urban area etc. Based on image signatures, supervised classification and final estimation of land use land cover coverage of the existing study area were recorded from the year of 1973 to 2009 (Table 5). Table 1 shows the Land Use classes of study area from topographic Map in 1973. Table 2 shows the Land Use classes of study area of Landsat data from 2000. Table 3 shows the Land Use classes of study area based on the Google Image Classification from 2009. Table 4 shows the coal mining area of Jamuna Kotma region.

\section{Result and Discussion}

Satellites data studies depicted that impact of coal mine have both positive and negative. Due to the mining topography of the area has been changed which have negative impact. Forest covers have been declined and its impacts can be visualized on biodiversity characterization, which is a negative sign of environmental impact. In 1973 forest area was 174 sq. km. In 2000 it reduced and remained as 96 sq. km and in 2009 forest area was only left $68 \mathrm{sq}$. $\mathrm{km}$. Water bodies have increase due to the mining activities. In 2000, mining area is was $47 \mathrm{sq} \mathrm{km}$. and in 2009 mining area was increased as $64 \mathrm{sq} \mathrm{km}$. Agriculture land has been reduced from 167 sq. km.(1973) to 110 sq. km. (2000) to $\mathbf{8 8 ~ s q . ~} \mathbf{~ k m}$ in 2009. This shows also a negative impact. Waste lands had been continuously increasing, due to increase in mining overburden dumping site. In 1973 it was $26 \mathrm{sq}$. km which becomes 84 sq.km in 2000 and 104 sq.km in 2009. Settlement has also shows increasing pattern. It covered 58 sq.km, 81 sq. km. and 93 sq.km in 1973, 2000, and 2009, respectively.

Table 1 Land Use classes of study area (1973)

\begin{tabular}{|c|c||c|c|c|}
\hline SN & \multicolumn{2}{|c|}{ Land use type } & Area (Sq.m.) & $\begin{array}{c}\text { Total Area } \\
\text { (sq.m.) }\end{array}$ \\
\hline \multirow{2}{*}{$\mathbf{1}$} & \multirow{2}{*}{ forest } & General & 90425543.1 & \multirow{2}{*}{174715645.1} \\
\cline { 3 - 4 } & & $\mathrm{PF}$ & 41342033.6 & \\
\cline { 3 - 4 } & & $\mathrm{RF}$ & 42948068.4 & \\
\hline $\mathbf{2}$ & Water body & Pond & 43656123.2 & \multirow{2}{*}{43996809.2} \\
\cline { 3 - 4 } & & Dry Pond & 340686.0 & \\
\hline $\mathbf{3}$ & Settlement & & 58192660.3 & 58192660.3 \\
\hline $\mathbf{4}$ & Wasteland & & 26475177.7 & 26475177.7 \\
\hline $\mathbf{5}$ & Agriculture & & 167793595.8 & 167793595.8 \\
\hline & \multicolumn{3}{|c|}{ TOTAL } & $\mathbf{4 7 1 1 7 3 8 8 8 . 1}$ \\
\hline
\end{tabular}

Table 2 Land Use classes of study area (2000)

\begin{tabular}{|c|c|c|}
\hline Class & Area (Ha.) & Area (Sq.m.) \\
\hline Agriculture & 11005.1931 & 110051931.00 \\
\hline Forest & 9621.0653 & 96210653.00 \\
\hline Mining & 4709.125 & 47091250.00 \\
\hline Settlement & 8124.3101 & 81243101.00 \\
\hline water & 5221.2013 & 52212013.00 \\
\hline waste Land & 8436.4940 & 84364940.00 \\
\hline TOTAL & $\mathbf{4 7 1 1 7 . 3 8 8 8}$ & $\mathbf{4 7 1 1 7 3 8 8 8 . 0 0}$ \\
\hline & & \\
\hline
\end{tabular}


Table 3 Google Image Classification (2009)

\begin{tabular}{|c|c|c|}
\hline Land Use Classes & Area (Sq KM) & Area in (Sq.m.) \\
\hline Agriculture & 88.041410 & 88041410 \\
\hline Forest & 68.112022 & 68112022 \\
\hline Mining & 64.601250 & 64601250 \\
\hline Settelment & 93.143101 & 93143101 \\
\hline water & 53.215003 & 53215003 \\
\hline waste Lend & 104.061102 & 104061102 \\
\hline Total & $\mathbf{4 7 1 . 1 7 3 8 8}$ & $\mathbf{4 7 1 1 7 3 8 8 8}$ \\
\hline
\end{tabular}

Table 4 Coal Mining Area

\begin{tabular}{|c|c|c|}
\hline S.N. & Name of Mine & $\begin{array}{c}\text { Area } \\
(\text { Sq. } \text { m })\end{array}$ \\
\hline 1. & Govinda colliery & 4650000 \\
\hline 2. & Meera Incline & 4682600 \\
\hline 3. & Kotma West open cast Mine & 6880500 \\
\hline 4. & Bartarai and Amadand Colliery & 6850000 \\
\hline 5. & Jamuna 9 \& 10 Inclines & $\mathbf{8 0 6 1 4 0 0}$ \\
\hline 6. & Bhadra colliery $7 \&$ \& Incline & 5583600 \\
\hline 7. & Jamuna open cast Mine & 10143150 \\
\hline 8. & Jamuna 1 \& 2 & 9090000 \\
\hline 9. & Amadand open cast mine & $\mathbf{8 6 6 0 0 0 0}$ \\
\hline & Total & 64601250 \\
\hline
\end{tabular}

Table 5. Landuse Changes from 1973 to 2000 to 2009Area in Square Meter

\begin{tabular}{|l|l|r||r|r|r||r|r|}
\hline S.N. & Land use type & Year 1973 & Year 2000 & Year 2009 & $\begin{array}{l}\text { Changes } \\
\text { between 1973 } \\
\text { to 2000 }\end{array}$ & $\begin{array}{l}\text { Changes } \\
\text { between 2000 } \\
\text { to 2009 }\end{array}$ & $\begin{array}{l}\text { Changes between } \\
\mathbf{1 9 7 3} \text { to 2009 }\end{array}$ \\
\hline $\mathbf{1 .}$ & Agriculture & 167793595.8 & 110051931 & 88041410 & -57741664.8 & -22010521 & -79752185.8 \\
\hline $\mathbf{2 .}$ & Forest & $\begin{array}{r}174 \\
\text { (15645.1 }\end{array}$ & 96210653 & 68112022 & -78504992.1 & -28098631 & -106603623.1 \\
\hline $\mathbf{3 .}$ & Mining & & 47091250 & 64601250 & +47091250 & +17510000 & +64601250.0 \\
\hline $\mathbf{4 .}$ & Settelment & 58192660.3 & 81243101 & 93143101 & +23050440.7 & +11900000 & +34950440.7 \\
\hline $\mathbf{6 .}$ & water & 43996809.2 & 52212013 & 53215003 & +8215203.8 & +1002990 & +9218193.8 \\
\hline & waste Land & 26475177.7 & 84364940 & 104061102 & +57889762.3 & +19696162 & +77585924.3 \\
\hline
\end{tabular}

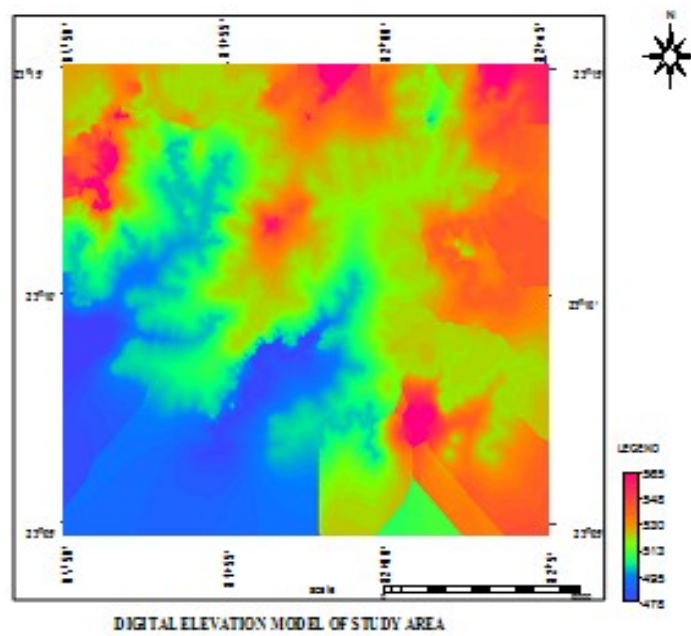

Fig.3 Digital Elevation Model of Area

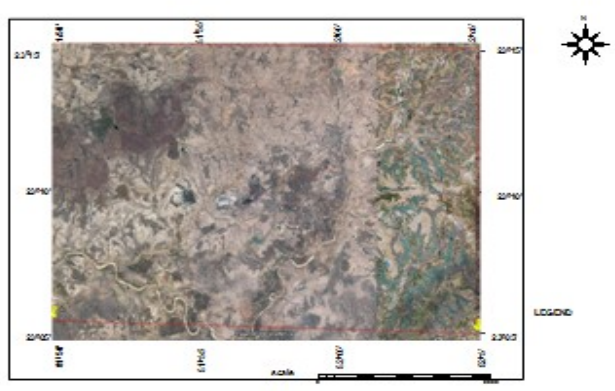

Fig 5. Google earth image of coal mines area 2000

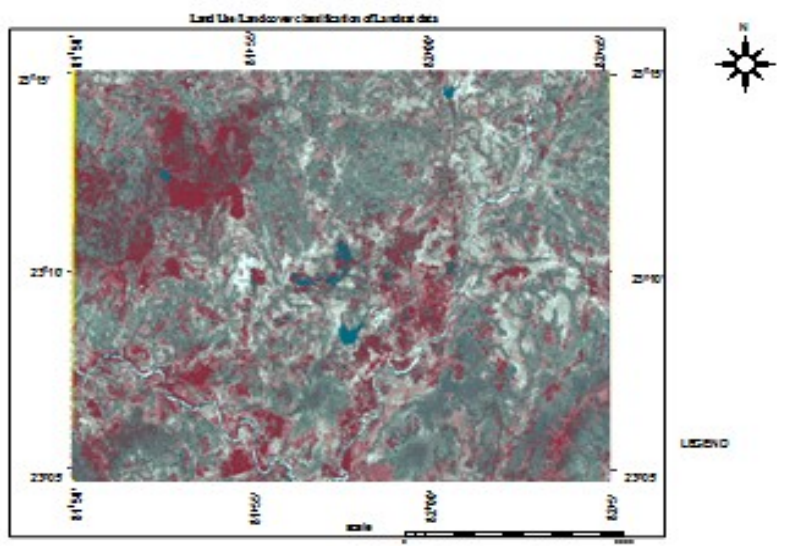

Fig 4. LU/LC classification of Year 2009

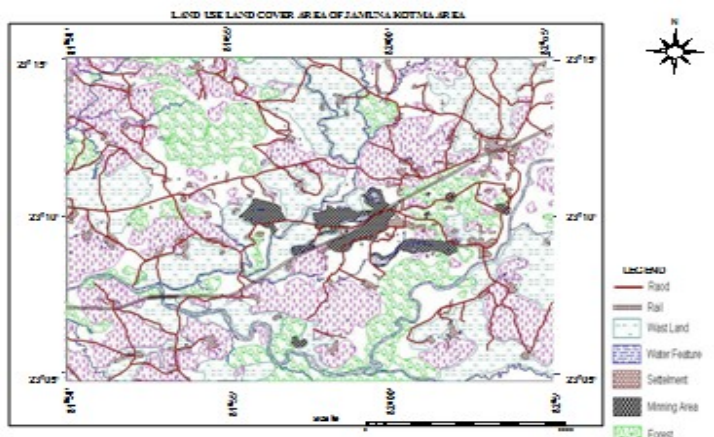

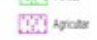

Fig 6. Land Use Land Cover of Year 2009 


\section{Acknowledgement}

The Authors are grateful to Sri S. Sinha, Senior Surveyor of Jamuna- Kotma Coal Mines for continuous support and provide secondary data of the mine area.

\section{References}

[1]. Bhaumik, A., and Tiwari, S.K., (2008), Image Classification (Land Use and Land Cover) of LANDSAT ETM 7 Imagery with the help of Image processing Software: A case study, Environmental Issues on Geotechnics and Mineral Industry. EIGMI, (Ed.) Karmakar and Jamal, pp.275-283.

[2]. Chaudhary, B. S., Saroha G. P., and Yadav, Manoj, (2008), Human Induced Land Use/ Land Cover Changes in Northern Part of Gurgaon District, Haryana, India, Natural Resources Census Concept J. Hum. Ecol., Vol. 23, No.3, pp. $243-252$.

[3]. Chitade, Anil Z, and Katyar, S.K., ( 2010), Impact analysis of open castcoal mines on land use/LandCover using remote sensing andgis technique: a case study, Int. J Engineering Science and Technology,Vol. 2 (12),pp.7171-7176

[4]. Dobson, M.C.L. Pierce., K. Sarabands., F.T. Ulaby and Terry Sharik, (1992).Preliminary analysis of ERS-1 SAR for Forest ecosystem studies, J, Geoscience and Remote Sensing,vol.30, pp.203-211.

[5]. Estes, J.E. and Simonenett, D.S., (1975), Fundamentals of Image interpretation, pp.869-2144

[6]. Garg J.K., and Baldev. Sahai (1989), Impact of mining on Environment. Discussion Meet on"The status of Environment". (Land and Soil). Its issues and problems. National Remote Sensing Agency.Hydrabad. pp. 9-10.

[7]. Javed, Akram,(2009), Land Use Changes due to Coal Mining Activities: A Case Study of Singrauli Coalfield, Central India, 2nd German-Indian Conference on Research for SustainabilityUnited Nations University, Bonn, 27-28.

[8]. Kuang Wenhui, Zhang Shuwen, Zhang Yangzhen,( 2007): Research on Estimating Urban Land Use Floor Area in Chaungchun Based on High Resolution Satellite Images. Journal of Chongqing Jianzhu University, Vol. 29, No. 1

[9]. Kushwaha, S.P.S., and Oesten, G., (1995), A rule based system for forests land use planning. Photonirvachak, vol. 2, no.3, pp.115125.

[10]. Kushwaha, S.P.S., Roy, P.S., Azeem, A. Brouah, P. and Lahan, P.,(2000), Land area change and habitat suitability analysis in Kaziranga National Park Assam, Tiger Paper Vol.27,No. 2, pp.9-17.

[11]. Majumdar. S., and Sarkar, K., (1994), Impact of mining and related activities on physical and cultural environment of Singarauli coal fields. Journal of the Indian Society of remote sensing (photonirvachhark), vol. 22, no.1, pp. 45-56

[12]. Peter, Van. Oosterom, Siyka. Zlatanova, Elfriede M. Fendel, (2005), Geo-information for Disaster Management. Published on Springer. ISBN: 3540249885 .

[13]. Prakash, A., Gupta, R. P. and Saraf, A. K., A (1997), Landsat TM based comparative study of surface and subsurface fires in the Jharia coalfield. India Int. J. Remote Sensing, Vol. 18, pp. 2463-2469.

[14]. Saraf, A. K., Prakash, A., Sengupta, S. and Gupta, R. P., (1995), Landsat- TM data for estimating ground temperature and depth of subsurface coal fire in the Jharia coalfiled, India. Int. J. Remote Sensing, Vol.16, pp. 2111-2124.

[15]. Saxena. R. and D.K. Pandey (1992), Impact of mining and mining based based industries on Land use/ Land cover and its surrounding environment environment by Remote sensing technique Proc. Nat. Symp.On Remote Sensing For sustainable development.pp.8-80.

[16]. Sinha A.K., Srivastav, V.C., and Nagar, M., (1982), Land Degradation around Singrauli An observation, Proc. Fourth intern. Conr.Eng. Geol., Oxford \& I.B.H., New Delhi, 1, pp. 57-68.

[17]. Singh, Prabhbir and Khanduri, Kamlesh (2011): Land use and Land cover change detection through Remote Sensing \&GIS Technology: Case study of Pathankot and Dhar Kalan Tehsils, Int. J. Geomatics and Geosciences, Vol 1, No 4,

[18]. Tomas, Gremlica, (2007), Renewal of Ecological and Aesthetic Functions of the Kladno Landscape in Parts Disturbed by the Mining of Black Coal. 11th Conference on Environment and Mineral Processing Part III, pp.389-394. ISBN: 9788024814315.

[19]. Tripathi, Shashikant, Singh, Ravindra and Mishra,Smita (2007): Land use/ Land cover mapping, change detection and suitable site for medical plant using GIS;With special refrence to industrialization of Pithampur area of Indore and Dhar District, Proceedings National Seminar, Faculty of Engineearing and Technology M.G.C.G.V. Chitrakoot Satna, pp.44-48. 